\title{
Заходи фізичної терапії та ерготерапії, спрямовані на відновлення якості життя в осіб з ушкодженнями периферичних нервів верхньої кінцівки після реконструктивно-відновлювальних операцій
}

\author{
УДК: 615.825:616.833 \\ О. Б. Лазарєва, О. В. Бісмак
}

Національний університет фізичного виховання і спорту України, Київ, Україна

\begin{abstract}
Резюме. Мета. Охарактеризувати основні заходи фізичної терапії та ерготерапії, спрямовані на відновлення якості життя в осіб з ушкодженнями периферичних нервів верхньої кінцівки після реконструктивно-відновлювальних операцій. Матеріал і методи. У дослідженні брали участь 252 пацієнти, які були рандомізовані на дві групи: основну (127) та групу порівняння $(\mathrm{n}=125)$. Використано методи аналізу, синтезу та узагальнення даних науково-методичної літератури та Інтернет-джерел, контент-аналіз медичних карт хворих, реабілітаційне обстеження. Результати. На основі контент-аналізу медичних карток та реабілітаційного обстеження ми розробили для пацієнтів основної групи комплекс реабілітаційних заходів відповідно до МКФ. На рівні структури і функції із засобів фізичної терапії ми застосовували: кінезитерапію (пасивні, пасивно-активні, активні вправи), нейродинамічні техніки, ПНФ, ортезування, масаж, апаратну фізіотерапію. Із засобів ерготерапії ми використовували розвивальну стратегію, яка включала дзеркальну терапію, терапію дії та спостереження, заняття на тренажері ARAT. Ha рівні активності кінезитерапевтичні заняття доповнювалися пасивно-активними, активними вправами, застосовували спеціальні вправи для дрібної моторики, силове тренування, ПНФ, масаж, гідрореабілітація, тренажерні технології, тейпування. Ерготерапія була компенсаторного характеру, направлена на більш активне включення пацієнтів у виконання побутових дій - СІМТ-терапія, дзеркальна терапія, бімануальна терапія. На рівні участі ми доповнювали комплекс реабілітаційних заходів віртуальними тренажерами (інтерактивні відео-ігри для верхньої кінцівки) та завдання-орієнтованим тренуванням. Висновки. Розроблений комплекс реабілітаційних заходів в основній групі пацієнтів з наслідками травматичних та компресійних невропатій верхньої кінцівки був спрямований на прискорення регенерації уражених нервових волокон, профілактику контрактур, атрофії м'язів, відновлення маніпулятивної та статодинамічної функції руки, самообслуговування у повсякденному житті та покращення якості життя. Ключові слова: фізична терапія, ерготерапія, травматичні невропатії, нейродинаміка, масаж, СІМТ-терапія, зеркальна терапія, ПНФ.
\end{abstract}

Measures of physical therapy and occupational therapy aimed at restoring the life quality of persons with damage of the upper extremity peripheral nerves after reconstructive-recovery operations

\section{O. B. Lazarieva, O. V. Bismak}

National University of Ukraine on Physical Education and Sport of Ukraine, Kyiv, Ukraine

Abstract. Objective. To characterize the main measures of physical therapy and occupational therapy aimed at recovering the life quality of persons with injuries of the upper extremity peripheral nerves after reconstructive surgery. Material and methods. The study involved 252 patients who were randomized into 2 groups: the main group (127 patients) and the comparison group $(n=125)$. Methods of analysis, synthesis and generalization of scientific and methodological literature data, Internet sources, content analysis of medical records of patients, rehabilitation examination were used. 
Results. Based on the content analysis of medical records and rehabilitation examination, a set of rehabilitation measures for patients of the main group was developed in accordance with the ICF. At the level of structure and function the following methods of physical therapy were used: kinesiotherapy (passive, passive-active, active exercises), neurodynamic techniques, PNF, orthosis, massage, apparatus physiotherapy. Of occupational therapy methods, a developmental strategy, including mirror therapy, action and observation therapy, and exercises on the ARAT simulator were used. At the level of activity, kinesiotherapy classes were supplemented by passive-active, active exercises, special exercises for fine motor skills, strength training, PNF, massage, hydrotherapy, training technologies, and taping. Occupational therapy was of a compensatory nature, aimed at more active inclusion of patients in domestic activities - CIMT therapy, mirror therapy, bimanual therapy. At the participation level, we supplemented the complex of rehabilitation measures with virtual simulators (interactive video games for the upper limb) and task-oriented training. Conclusions. The developed set of rehabilitation measures in the main group of patients with the consequences of traumatic and compression neuropathies of the upper limb was aimed at accelerating the regeneration of affected nerve fibers, preventing contractures, muscle atrophy, restoring the manipulative and statodynamic functions of the hand, self-care in everyday life and improving the quality of life.

Keywords: physical therapy, occupational therapy, traumatic neuropathies, neurodynamics, massage, CIMT-therapy, mirror therapy, PNF.

Постановка проблеми. Аналіз останніх досліджень і публікацій. Одним із ключових положень, що визначають успішний розвиток системи реабілітації нейрохірургічних хворих, $€$ впровадження дослідження параметрів якості життя як інтегрального критерію ефективності проведених заходів [5]. Крім того, вивчення якості життя до і після реабілітаційних втручань дозволяє використовувати даний параметр як прогностичний фактор для визначення стратегії і тактики індивідуалізованого підходу до пацієнта. При цьому реабілітацію слід вважати успішною в тому випадку, якщо хворий, навіть за наявності залишкових явищ, повернувся до повсякденного життя [5].

Останнім часом у реабілітації з'явився новий термін - «якість життя, пов'язана зі здоров'ям». Багато авторів вважають, що саме на цей показник треба звертати особливу увагу. У неврологічній практиці при багатьох захворюваннях реабілітаційні заходи не повністю відновлюють порушені функції, а ефективність залежить не лише від характеру та інтенсивності реабілітації, а й від ступеня порушення рухових фуннкцій $[2,5]$.

Захворювання периферичної нервової системи, зокрема плечового сплетіння та нервів верхньої кінцівки, супроводжуються руховими (перифреричні парези та паралічі), чутливими (парестезії, гіпо- та гіперстезії), вегетативно-трофічними порушеннями в ураженій кінцівці, що значно знижує якість життя пацієнтів $[1,10]$.

Проте проблема застосування засобів фрізичної терапії та ерготерапії після хірургічного лікування компресійно-ішемічних $\mathrm{i}$ травматичних невропатій верхньої кінцівки продовжує залишатися дуже актуальною з огляду на щорічне збільшення кількості пацієнтів з тяжкими травмами перифреричних нервів руки та оперативних втру- чань для відновлення структури та фрункції нервових структур і руки постраждалого в цілому.

Мета дослідження - охарактеризувати основні заходи фізичної терапії та ерготерапії, спрямовані на відновлення якості життя в осіб з ушкодженнями перифреричних нервів верхньої кінцівки після реконструктивно-відновлювальних операцій.

Матеріал і методи дослідження. Проведено контент-аналіз 428 медичних карт хворих, із них 353 історії хвороби пацієнтів з наслідками травматичних та компресійних ушкоджень периферичних нервів верхньої кінцівки та 75 історій хвороби пацієнтів з компресійно-ішемічними (тунельними) невропатіями. Безпосередньо у дослідженні брали участь 252 пацієнти, які були рандомізовані на дві групи: основну $((n=127)$ та групу порівняння $(n=125)$. Усім хворим було виконано різні реконструктивні операції: ревізія пошкодженого нерва, невроліз, висічення бічних і кінцевих невром, шов нерва з імплантацією електродів, аутотрансплантація нервового стовбура та сухожилково-м'язові транспозиції.

У процесі дослідження використано методи аналізу, синтезу та узагальнення даних науковометодичної літератури та Інтернет джерел, контент-аналіз медичних карт хворих, реабілітаційне обстеження. Дослідження проводилося на базі ДУ «Інститут нейрохірургії ім. акад. А. П. Ромоданова НАМН України» та неврологічних відділень № 1 та № 2 Київської міської клінічної лікарні № 4 (2016-2019рр.).

Результати дослідження. Враховуючи тяжкі наслідки уражень периферичних нервів та плечового сплетіння руки - рухові, чутливі, вегетативно-трофрічні порушення, розвиток парезу чи периферичного паралічу, інвалідність, зниження якості життя - невід'ємними частинами процесу 
відновного лікування пацієнтів із травматичними та компресійно-ішемічними невропатіями верхньої кінцівки $є$ фрізична терапія та ерготерапія [3].

На основі контент-аналізу медичних карток та реабілітаційного обстеження ми розробили для пацієнтів основної групи комплекс реабілітаційних заходів, які були спрямовані на прискорення регенерації уражених нервових волокон, упередження атрофії м'язів, профрілактику контрактур, відновлення маніпулятивної та статодинамічної функції руки, самообслуговування у повсякденному житті та побуті, професійних дій. Усі заходи відновного лікування ми застосовували відповідно до основних доменів Міжнародної класифрікації фрункціонування, обмежень життєдіяльності та здоров'я (МКФ). У групі порівняння застосовували традиційні засоби фрізичної терапії та ерготерапії, які використовуються у лікувальних закладах.

Реабілітаційні заходи при невропатіях верхньої кінцівки включають:

1) проведення комплексного обстеження, оцінки, визначення потреб, пацієнта, прогнозів та плану заходів з фрізичної терапії та ерготерапії;

2) впровадження програми втручання;

3) визначення очікуваних результатів втручання;

4) надання рекомендацій для самостійного функціонування.

Одним із важливих етапів реабілітаційного процесу $€$ планування / визначення заходів фрізичної терапії та ерготерапії. Реабілітаційні втручання залежать від виду невропатії (компресійна, ішемічна, травматична), методу лікування (консервативний чи оперативний), ступеня ураження нерва (струс, забій чи здавлювання), частковий чи повний розрив нерва, періоду реабілітації та інших фракторів. Всі різновиди невропатій верхньої кінцівки об'єднує загальний характер виникаючих при них рухових порушень - млявий парез або параліч. У той же час різноманітність етіологічних факторів, що призводять до ураження периореричної нервової системи, визначає й істотні відмінності в підходах до відновного лікування цих хворих $[6,11]$.

На основі аналізу літературних, інтернет джерел, контент-аналізу медичних карт та реабілітаційного обстеження ми розробили комплекс реабілітаційних заходів для пацієнтів основної групи 3 компресійно-ішемічними і травматичними невропатіями верхньої кінцівки. Курс реабілітації тривав 6-12 міс. залежно від характеру травми. Засоби фрізичної терапії та ерготерапії представлено на рисунку 1.

На рівні структури і фрункції ми використовували такі засоби фрізичної терапії, як кінезите- рапія (пасивні, пасивно-активні, активні вправи), нейродинамічні техніки, ПНФ, ортезування. Із засобів ерготерапії - заняття на тренажері ARAT.

У більшості досліджень зазначається, що кінезитерапія $€$ одним з основних засобів фрізичної терапії при даній патології [2, 4]. За відсутності активних рухів застосовували: лікування положенням та ортезування; вправи для м'язів плечового поясу з метою поліпшення лімфо- i кровообігу; пасивні рухи у всіх суглобах паретичного сегмента або кінцівки з одночасним використанням уявних (ідеомоторних) вправ. Пізніше використовували активно-пасивні та активні вправи, які призначаються при стиханні больового синдрому. Спочатку активні рухи виконували у полегшених умовах (зменшення сили тяжіння кінцівки і сили тертя на робочій поверхні у поєднанні з одночасною тренуванням здорової кінцівки).

3 метою зменшення та усунення больового синдрому, запобігання набряку нерва і периневральних тканин, стимулювання провідності нерва та регенерації нервових волокон, поліпшення місцевого і загального крово- та лімфообігу, попередження утворення рубців на місці пошкодження, запобігання або усунення трофрічних розладів, тугорухливості в суглобах, контрактур та інших змін, що перешкоджають відновленню рухів верхньої кінцівки, ми використовували нейродинамічні техніки [7]. Виконання такої методики здійснювали шляхом поетапного застосування згинальних, розгинальних рухів та ротації за допомогою рук фрізичного терапевта за чітко заданими орієнтирами. Проводили мобілізацію рухів нерва вгору-вниз, ковзання по довжині каналу, іноді розтягнення до повного відновлення.

Ортези та кінезитейпуВання ми призначали хворим передусім при стійкій втраті фрункцій кінцівки для здійснення побутових і виробничих операцій, освоєння прийомів самообслуговування. Вони також застосовувалися для закріплення результатів відновного лікування, розробки рухів у суглобах, тренування м'язів.

Одним із методів фрізичної терапії, який ми включили в комплекс реабілітаційних заходів, був метод пропроцептивної нейром'язової фосилітації (ПНФ) [13, 16]. У цьому методі використовували вправи, що призводять до активного м'язового скорочення зі збудженням максимального числа рухових одиниць і залученням їх у вольову активність. Вправи включали в комбінацію рухів одночасно кілька суглобів і три компоненти рухів - згинання або розгинання, приведення або відведення і внутрішню або зовнішню ротацію. 


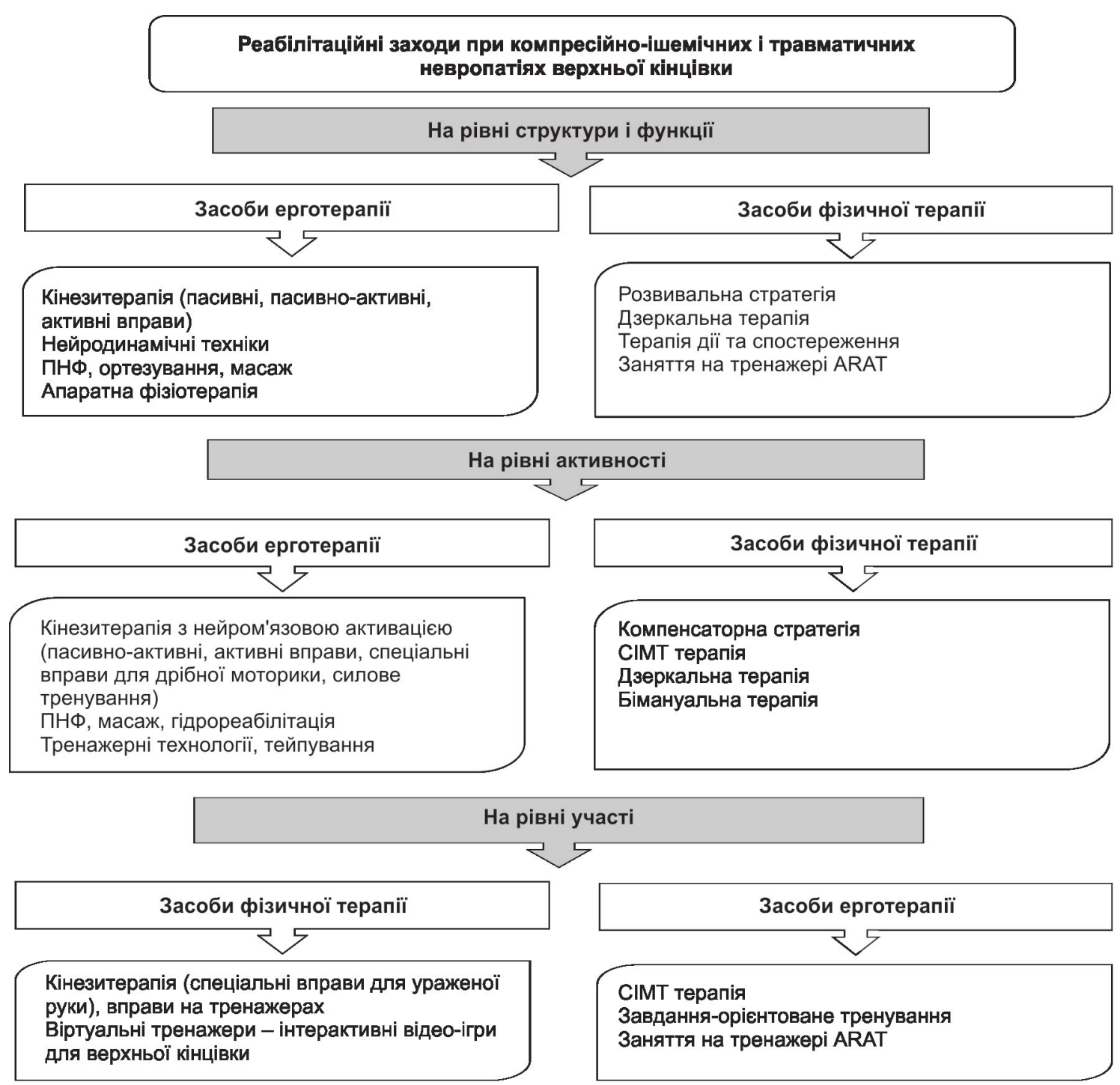

Рисунок 1 - Блок-схема реабілітаційних заходів при невропатіях верхньої кінцівки

Ерготерапія є складовою частиною реабілітаційного процесу неврологічних хворих. Засоби ерготерапії ми використовували не тільки для відновлення втрачених фоункцій, а й для адаптації пацієнтів до нормального життя, досягнення максимальної самостійності, мобільності у побуті та у повсякденному житті.

На рівні структури і фрункції ми застосовували розвивальну стратегію ерготерапії: дзеркальну терапію, терапію дії та спостереження, заняття на тренажері/тесті ARAT.

Дзеркальна mерапія. Суть методу полягає в тому, що перед хворим у сагітальній площині розташовують дзеркало таким чином, що в ньому відбивається здорова кінцівка. При цьому зоровий контроль здійснюється лише за здоровою кінцівкою і її відображенням, що створює у хворого зорову ілюзію, ніби обидві половини тіла функціонують належним чином. Рухи ураженої кінцівки, які також намагається здійснити хворий, коригуються ерготерапевтом відповідно до рухів здоровою рукою. Спостереження за відбитим у дзеркалі рухом здорової кінцівки стимулює активність моторної кори головного мозку, при цьому темпи реабілітації прискорюються [12, 14, 17].

Терапія діï та спостереження. У пацієнтів 3 наслідками травматичних та компресійних уражень периферичних нервів верхньої кінцівки спостерігаються труднощі з рухом рук (парез) або повна відсутність довільних рухів (параліч), що призводить до проблем у повсякденній діяльності і скорочення участі в ній. Терапія дії і спостереження - це підхід до реабілітації руки, згідно 3 яким пацієнт 3 даною патологією спостерігає за здоровими людьми (за фрізичним терапевтом/ 
ерготерапевтом, родичами, людьми, що доглядають/допомагають хворому), які виконують будь-які дії - на відео або особисто - потім повторює їх (наскільки це можливо чи намагається виконати мінімальні рухи). Дослідження, проведені в різних країнах, показують, що терапія дії і спостереження активує ділянки мозку таким чином, якщо б пацієнт сам виконував ті самі дії, і може поліпшити відновлення рухової фрункції руки [7].

3 метою відновлення здатності пацієнта обробляти об'єкти різних розмірів, ваги і фрорми захоплення ми застосовували заняття на тренажері/mесті ARAT. Цей тренажер тренує утримання різних предметів (стакана, м'яча, шайби, кілочків, дерев'яних кубиків тощо), різні види захватів ураженою рукою (шаровий, пінцетоподібний), дрібну та велику моторику.

На ріВні актиВності. Для відновлення та збільшення сили м'язів та рухливості в суглобах ураженої кінцівки застосовували кінезитерапію з нейром'язовою актиВацією (пасивно-активні, активні вправи, спеціальні вправи для дрібної моторики, силове тренування), ПНФ, стимулюючий масаж, гідрореабілітація, тренажерні технології, тейпування.

Одним 3 напрямів фрізичної терапії $€$ активно-пасивна механотерапія 3 використанням спеціальних тренажерів для верхньої кінцівки. Пацієнти основної групи займалися на універсальному тренажері (стіл реабілітаційний) для руки. Виконували вправи для кисті, пальців без навантаження та з певним навантаженням. Крім того, застосовували тренажери для кисті Xtrainer Thera-Band та Thera-Band Hand Xtrainer з різною еластичністю (початковий, середній та просунутий рівні). Для відновлення рухливості суглобів кисті і пальців використовували тренажери Kinetec MAESTRA та ARTROMOT [8].

Масаж у даної категорії пацієнтів застосовували для покращення трофіки шкіри, активації місцевого і загального лімфо- та кровообігу, підвищення тонусу і скоротливої фрункції м'язів, попередження розвитку м'язової атрофрії, прискорення ффункціонального відновлення при рухових розладах. Особливістю масажу при периферичних парезах/паралічах, які розвиваються при важких формах невропатій, $є$ його диференційована дія на м'язи, чітке дозування інтенсивності, сегментарно-рефлекторний характер дії. Застосовували масаж ураженої верхньої кінцівки стимулюючого характеру, включаючи непереривну вібрацію, допоміжні прийоми - струс і поштовхи, що викликають великий потік пропріоцептивних імпульсів у центральну нервову систему [4].
Спортивна медицина і фізична реабілітація, № 1, 2020

Ерготерапія. Відомо, що рухові порушення (периферичні парези та паралічі), які виникають при травматичних невропатіях верхньої кінцівки, ускладнюють рухи руки. Наприклад, стає важко дотягнутися, схопити будь-які об'єкти і управляти (переміщати) їми. У свою чергу, це викликає багато труднощів під час виконання дій у повсякденному житті, таких, як умивання, самостійне одягання, прийом їжі і догляд за собою. 3 метою активного залучення ураженої кінцівки у повсякденні дії в основній групі пацієнтів ми використовували терапію обмеженням руху (CIMT-mepaniя). Під час CIMT-терапії дії здорової руки обмежують так, щоб вона не могла бути використана. Це означає, що замість неї доводиться використовувати пошкоджену руку. Рухам здорової руки і кисті перешкоджали за допомогою рукавички або спеціального підлокітника [9].

Реабілітацію за методом СІМТ ми регламентували часом обмеження рухів здоровою рукою, обсягом активних рухів, які необхідно було виконувати постраждалою рукою. Здорова рука знаходилася без руху за допомогою пов'язки або спеціальної рукавички, і в той же час протягом 3-6 год. в день проводилися спеціально підібрані вправи для ураженої руки. Даний підхід також дозволяє подолати феномен «невикористання» оперованої кінцівки.

Також із засобів ерготерпаії ми використовували бімануальну терапію руки - техніку, яка використовує завдання, що потребують спільної роботи двох рук (наприклад, наливання води в стакан). Бімануальну терапію ми рекомендували для осіб з низьким рівнем фрункціонування верхньої кінцівки (при паралічах) і на ранніх етапах після операції [8].

На рівні участі. Фізична терапія. Застосовували кінезитерапію (спеціальні вправи для дрібної та великої моторики). Пацієнти продовжували займатися на тренажерах. Як доповнення до кінезитерапії і тренажерної реабілітації ми рекомендували хворим використовувати інтерактивні відео-ігри для верхньої кінцівки, щоб збільшити кількість часу, що витрачається пацієнтами на лікування та підвищити їх зацікавленість та мотивацію.

Ерготерапія. Заљдання-орієнтоване тренуВання в реабілітації фрокусується на поліпшення функціональної активності завдяки цілеспрямованій практиці та повторенню. В основі - тренування функціональних завдань, під час якого пацієнти виконують специфрічні повторювані завдання, які полегшують моторне відновлення оперованої руки. На відміну від простих узагальнених рухових вправ, нейровізуалізація виявила 
більший ступінь і стійкість реорганізації кори головного мозку. Це може бути частина завдання або завдання повністю, які виконуються повторно, та $є$ частиною заняттєвої активності людини. Повторення включає всі або поєднання чотирьох основних компонентів руху: дотягування, хапання, переміщення/маніпулювання предметами, відпускання предмета $[15,18]$.

Використання завдання-орієнтованого тренування у клінічній практиці передбачає застосування таких стратегій впровадження за доказовою базою:

- тренування конкретних завдань повинно бути значущим для пацієнта/клієнта;

- використовуватися у різних заняттях (випадково розподілене);

- багато разів повторюване;

- спрямоване до відновлення цілого (заняття);

- бути підкріпленим та позитивним та вчасним звоторнім зв'язком.

Приклади фрункціональних завдань: відкрити/закрити кран (водопровідний), відчинити та зачинити двері; брати та піднімати пляшку; перегортати карти з колоди; збирати невеликі намистини та складати їх в ємність; складати аркуш паперу навпіл; наливати воду з глечика в чашки; здійснювати маніпуляції із застібками одягу (ґудзики, блискавки тощо), натискати на порожню пляшку (з-під шампуню, напою тощо), гортати сторінки книги; відкривати ключем замок; надягати та знімати одяг.

Також пацієнти основної групи продовжували застосовувати CIMT-терапію і заняття на тренажері/тесті ARAT, збільшуючи час занять.

Висновки. Розроблений комплекс реабілітаційних заходів в основній групі пацієнтів з наслідками травматичних та компресійних невропатій

\section{Література}

1. Борзых НА, Борзых АВ, Труфанов ИМ, Погориляк АИ. Восстановление моторики предплечья при нарушении проводимости импульса по длинным ветвям плечевого сплетения [Recovering motility of the forearm during violation of impulse conduction along the long branches of the brachial plexus]. Травма. 2013;14(3):68-9.

2. Воронін ДМ, Павлюк ЄО. Фізична реабілітація при захворюваннях нервової системи [Physical rehabilitation for diseases of the nervous system]. Хмельницький: ХНУ, 2011. 143 с.

3. Емельянов АЮ, Барсуков ИН, Андреева ГО. Комплексная терапия посттравматических плечевых плексопатий [Combined therapy for post-traumatic brachial plexopathies]. Медико-биологические и социально-психологические проблемы безопасности в чрезвычайных ситуациях. 2010; 2: $25-8$.

4. Козьолкін ОА, Візір IB, Сікорська МВ, Лапонов ОВ. Реабілітація пацієнтів з захворюваннями нервової системи [Rehabilitation of patients with diseases of the nervous system]. Запоріжжя: ЗДМУ, 2019. 183 c.

5. Малкова АА, Осетров АС, Шайдуров КА, Штеннес РА. Качество жизни неврологических больных [The quality of life of neurological patients]. верхньої кінцівки був спрямований на прискорення регенерації уражених нервових волокон, упередження атрофії м'язів, профрілактику контрактур, відновлення маніпулятивної та статодинамічної функції руки, самообслуговування у повсякденному житті та покращення якості життя. Сучасні засоби фрізичної терапії та ерготерапії ми диференціювали відповідно до основних положень МКФ: рівень структури, фрункції, активності та участі. Так, на рівні структури і фрункції із засобів фрізичної терапії ми застосовували: кінезитерапію (пасивні, пасивно-активні, активні вправи), нейродинамічні техніки, ПНФ, ортезування, масаж, апаратну фрізіотерапію. Із засобів ерготерапії ми використовували розвивальну стратегію, включаючи до комплексу відновлювальних заходів дзеркальну терапію, терапію дії та спостереження, заняття на тренажері ARAT.

На рівні активності кінезитерапевтичні заняття доповнювалися пасивно-активними і активними вправами, застосовували спеціальні вправи для дрібної моторики, силове тренування, ПНФ, масаж, гідрореабілітація, тренажерні технології, тейпування. Ерготерапія була компенсаторного характеру, направлена на більш активне включення пацієнтів у виконання побутових дій CIMT-терапія, дзеркальна терапія, бімануальна терапія.

На рівні участі ми доповнювали комплекс реабілітаційних заходів віртуальними тренажерами (інтерактивні відео-ігри для верхньої кінцівки) та завдання-орієнтованим тренуванням.

Перспективи подальших досліджень. У перспективі планується розробка практичних рекомендацій щодо застосування засобів фрізичної терапії та ерготерапії для даної категорії пацієнтів.

Синергия наук. 2017;11:704-708. - URL: http://synergy-journal.ru/archive/ article0529

6. Новиков МЛ, Торно ТЭ. Травматические повреждения плечевого сплетения: современные способы хирургической коррекции. Часть II. Тактика лечения повреждений плечевого сплетения [Traumatic injuries of the brachial plexus: modern methods of surgical correction. Part II Tactics for the treatment of injuries of the brachial plexus]. Нервно-мышечные болезни. 2013; 1: 18-25.

7. Солодянкин $\mathrm{EE}$, Бурмистров АЛ. Нейромышечная активация как современный метод восстановительного лечения больных вертеброгенной патологией [Neuromuscular activation as a modern method of rehabilitation treatment of patients with vertebrogenic pathology]. Медицинские новости. 2013;5:48-9.

8. Черникова ЛА. Инновационные технологии в нейрореабилитации [Innovative technologies in neurorehabilitation]. Москва: МИА; 2016. $344 \mathrm{c}$.

9. Таровская АМ, Прокопенко СВ. Применение метода СІ-терапии в нейрореабилитации [The use of $\mathrm{Cl}$ therapy in neurorehabilitation]. Сuбирское медицинское обозрение. 2015; 3: 33-7. 
10. Третяк IБ, Чеботарьова ЛЛ, Третьякова АІ. Діагностика та лікування хворих з ушкодженнями, переважно, верхнього стовбура плечового сплетення [Diagnosis and treatment of patients with injuries, mainly of the upper trunk of the brachial plexus] [Електронний ресурс]. Український нейрохірургічний журнал. 2010; 3: 57. Режим доступу: http:// nbuv.gov.ua/ UJRN/Unkhj_2010_3_104.

11. Цимбалюк ВІ, Страфун СС, Гайко ОГ, Гайович ВВ. Концепція відновлення функції кінцівки при травматичному ушкодженні периферичних нервів [The concept of recovery of limb function in traumatic injury of peripheral nerves]. Український нейрохірургічний журнал. 2016; 3: 48-54.

12. Antoniotti P, Veronelli L, Caronni A, Monti A, Aristidou E, Montesano M. No evidence of effectiveness of mirror therapy early after stroke: an assessor-blinded randomized controlled trial. Clinical Rehabilitation. 2019; 33(5): 885-93. doi: $10.1177 / 0269215518824737$.

13. Bertinchamp U. Concept PNF: facilitation proprioceptive neuromusculaire (concept Kabat-Knott-Voss). EMC - Kinésithérapie-Médecine physiqueRéadaptation, 2010; 1-9. doi: 10.1016/S1283-0887(10)51680-3.
Спортивна медицина і фізична реабілітація, № 1, 2020

14. Fong KN, Ting KH, Chan CC. Mirror therapy with bilateral arm training for hemiplegic upper extremity motor functions in patients with chronic stroke. Hong Kong Medical Journal. 2019; 25(3): 30-4. Retrieved from https://www. hkmj.org/system/files/hkmj1902sp3p30.pdf.

15. Peurala SH, Kantanen MP, Sjogren T, Paltamaa J, Karhula M, Heinonen A. Effectiveness of constraint-induced movement therapy on activity and participation after stroke: a systematic review and meta-analysis of randomized controlled trials. Clin Rehabil. 2012; 26(3): 209-23.

16. Singh K, Arora L, Arora R. Effect of proprioceptive neuromuscular facilitation (PNF) in improving sensorimotor function in patients with diabetic neuropathy affecting lower limbs. International Journal of Physiotherapy, 2016 3(3): 332-6. doi.org/10.15621/ijphy/2016/v3i3/100840.

17. Thieme H, Mehrholz J, Pohl M, Dohle C. Mirror therapy for improving motor function after stroke. Cochrane Database of Systematic. 2010.

18. Uswatte G, Taub E. Constraint-Induced Movement Therapy. Progress in Brain Research. 2013; 379-401. doi:10.1016/b978-0-444-63327-9.00015-1. 